\title{
ANALISIS PEMBENTUKAN PORTOFOLIO OPTIMAL DENGAN METODE STOCHASTIC DOMINANCE DAN SINGLE INDEX MODEL PADA SAHAM INDUSTRI REAL ESTATE AND PROPERTY DIBURSA EFEK INDONESIA
}

\author{
Eftika Riya Ningrum, Yuni Utami \\ Program Studi Manajemen \\ Fakultas Ekonomi dan Bisnis Universitas Pancasakti
}

\begin{abstract}
This study aims to see whether there is a difference between the stochastic dominance method and the single index method in forming an optimal portfolio. And see which method is more optimal. The sample used in the study was a real estate and property company listed on the IDX period (2013 -2017) using purposive sampling and analysis sampling techniques using the average difference test. After being tested with each method both modelstochastic and single index model, the results showed that there were differences in returns from the formation of an optimal portfolio with the test results which obtained the results of 0.048 under a significant level of 0.05 . And the results of the portfolio return calculation formed by the stochastic method smaller 0.0079 than the portfolio return formed by the single index method of 0.0173 which means that the single index method is more optimal than the stochastic method.
\end{abstract}

Keywords: Return, Optimal Portfolio, Stochastic Dominance, Single Index

\section{PENDAHULUAN}

\section{Latar Belakang Masalah}

Investasi merupakan komitmen atas sejumlah dana atau sumber daya lain yang dilakukan saat ini dengan tujuan agar dapat memperoleh keuntungan di masa yang akan mendatang atau bertujuan untuk meningkatkan kesejahteraan investor. (Hartono, 2016:5) Investasi merupakan penundaan dari suatu konsumsi pada saat sekarang yang akan dimasukkan ke dalam aktiva yang produktif selama periode waktu yang tertentu.Investasi apabila dilihat dari ruang lingkupnya terbagi menjadi dua yaitu investasi aktiva nyata dan investasi aktiva finansial.Investasi aktiva nyata merupakan investasi yang bentuknya dapat dilihat secara fisik.Investasi aktiva finansial merupakan investasi dengan bentuk surat- surat berharga.Misalnya deposito, obligasi, saham, dan lainlain.Ada dua cara dalam berinvestasi aktiva finansial, yaitu investasi langsung dan investasi tidak langsung.

Pasar modal merupakan penghubung antara investor (pihak yang memiliki dana) dengan perusahaan (pihak yang memerlukan dana jangka panjang) ataupun institusi pemerintah melalui perdagangan instrumen melalui jangka panjang, seperti surat berharga yang meliputi surat pengakuan utang, surat berharga komersial (commercial paper), saham, obligasi, tanda bukti hutang, waran (warrant), dan right issue. Saham merupakan salah satu instrument yang diperjual belikan dipasar modal dan termasuk dalam asset berisiko. Namun sebelum menentukan berinvestasi ada beberapa faktor yang harus diperhatikan oleh investor seperti 
berapa besar modal yang akan ditanamkan, jangka waktu penanaman modal, tingkat risiko yang akan ditanggung, dan return yang akan diperoleh. Jika investor menginginkan return yang tinggi maka risiko yang akan ditanggungpun tinggi.Salah satu pilihan investasi adalah dengan membentuk portofolio agar dalam investasi lebih optimal karena dapat mengurangi resiko. Melihat pesatnya pembangunan sektor perusahaan yang bergerak dibidangreal estate and propertyyang semakin menjanjikan hasil bagi para investor untuk berinvestasi.Dengan makin pesatnya pembangunan investor tertarik untuk menanamkan modalnya pada perusahaan real estate and property.Seorang investor sebelum melalukan investasi hendaknya memperhatikan proses tahapan investasi. Ada lima tahapan untuk menentukan keputusan investasi, yaitu

Penentuan tujuan investasi.

Penentuan kebijakan investasi.,

Pemilihan strategi portofolio.,

Pemilihan asset.Dan (4) Pengukuran dan evaluasi kinerja portofolio.Setiap investor selalu mengharapkan return dari setiap investasi yang dilakukan. Disisi lain ketika investor mengaharapkan return pasti ada risiko yang selalu melekat dan berkorelasi positif dengan return yang diharapkan investor. Semakin besar risiko yang ditanggung maka semakin besar return yang dikompensasikan, adanya risiko dalam investasi membuat investor harus melakukan cara-cara yang tepat untuk meminimalkan risiko yag mungkin terjadi. Investor tidak tahu pasti hasil yang akan diperoleh sehingga investor perlu melakukan diversifikasi untuk mengurangi risiko. Diversifikasi ini dilakukan dengan mengkombinasikan berbagai sekuritas dalam investasi atau membentuk portofolio. Dalam berinvestasi investor tidak berhenti pada diversifikasi untuk mengurangi risiko, namun juga para investor menginginkan return yang optimal dari investasi yang dilakukan.Pada pembentukan portofolio optimal terdapat beberapa metode.Penelitian ini akan mengulas dua metode yang digunakan dalam membentuk portofolio optimal, yaitu dengan menggunakan metode stochastic dominance dan single index model.

Stochastic dominancemerupakan teknik yang tidak memperhatikan bagaimana distribusi tingkat keuntungan investasi - investasi yang sedang dipertimbangan.Dengan kata lainstochactic dominance tidak menyaratkan distribusi tingkat keuntungan harus bersifat normal.Stochastic dominance menggunakan tiga asumsi yaitu first order, second order dan third order.First order stochastic dominance menyatakan bahwa pemodal lebih menyukai yang banyak dari pada sedikit.Second order stochastic dominance menyatakan bahwa pemodal bersikap tidak menyukai risiko. Sedangkan third order stochastic dominance menyatakan bahwa pemodal mempunyai decreasing absolute risk aversion (Husnan, 1998: 146).Hartono (2016:427) menjelaskan bahwasingle index model didasarkan pada pengamatan bahwa harga dari suatu sekuritas berfluktuasi searah dengan indeks harga pasar. Suad Husnan, (1998:103) juga memberikan penjelasan berkaitan dengan model index tunggal mendasarkan pemikiran bahwa tingkat keuntungan pasar berkorelasi dengan perubahan pasar. Model ini banyak digunakan sebagai alat analisis untuk mendapatkan portofolio yang efisien, karena model ini memungkinkan untuk dapat memmberikan return yang optimal.Pengujian portofolio optimal dengan metode single index model (indeks tunggal) telah membuktikan 
bahwa model ini memungkinkan untuk mendapatkan kinerja portofolio saham yang optimal.Penelitian yang dilakukan (Yuniarti dan Sari :2010) terhadap saham - saham perbankkan menghasilkan kombinasi portofolio yang paling optimal dan ukuran kinerja portofolio dalam investasi menunjukkan kinerja yang sangat efisien dengan menghasilakan return yang lebih tinggi dibandingkan return pasar. Achmad K, dkk (2014),M Ichsanuddin (2016)analisis melakukan penelitian pembentukan portofolio optimal dengan menggunakan model indeks tunggal dan stochastic dominanceuntuk pengambilan keputusan investasi pada saham yang masuk dalam indeks Sri-Kehati di Bursa Efek Indonesia dan perusahaan retail dan perdaganganM Ichsanuddin (2016)..return portofolio lebih tinggi dengan single indeks dibandingkan dengan stochastic dominance.Lilik Andriyani,, dkk (2016) Menggunakan Capital Asset Pricing Model (CAPM) Dan Stochastic Dominance. Dengan menggunakan 20 saham dari indeks sri kehati yang Hasil penelitian mengindikasi bahwa secara signifikan terdapat perbedaan return dan risiko portofolio antara pemilihan saham menggunakan Capital Asset Pricing Model (CAPM) dengan pemilihan saham menggunakan stochastic dominance.dan model stochastic lebih baik dibandingan dengan model CAPM. Sedangkan Windi Martya dkk (2014), Putu Putra dan Ni Ketut (2015) juga melakukan hal yang sama meneliti untuk mengetahui komposisi portofolio yang optimal dengan proporsi dana yang digunakan untuk berinvestasi dalam portofolio dengan menggunakan saham LQ45 . Dari hasil perhitungan tersebut menunjukkan bahwa risiko portofolio lebih kecil dibandingkan dengan risiko saham sebelum portofolio. Hal ini menunjukkan bahwa dengan membentuk portofolio optimal dapat menurunkan besarnya risiko.

Dari berbagai latar belakang penelitian sebelumnya penulis tertarik untuk menginvestigasi kembali komparatif model dengan perusahaan disektor yang berbeda sehingga dirumuskan permasalahan sebagai berikut:

Apakah ada perbedaan return antara portofolio yang dibentuk menggunakan stochastic dominance dengan portofolio yang dibentuk dengan metode single index model?

Apakah portofolio yang dibentuk menggunakan stochastic dominance lebih optimal dibandingkan portofolio yang dibentuk menggunakan single index model?

Apakah portofolio yang dibentuk menggunakansingle index model lebih optimal dibandingkan portofolio yang dibentuk menggunakan stochastic dominance?

Berdasarkan rumusan masalah diatas penelitian bertujuan untuk mengetahui perbedaan return yang dihasilkan oleh pembentukan portofolio menggunakan metode stochastic dominance dan menggunakan metode single index model, mengetahui seberapa optimal portofolio yang dibentuk menggunakan stochastic dominance dan untuk mengetahui seberapa optimal portofolio yang dibentuk menggunakan single index model.Sehingga dapat dirumuskan hipotesis penelitian sebagai berikut :

H1 : Ada perbedaan return portofolio antara pemilihan saham menggunakan stochastic dominance dengan pemilihan saham menggunakan single index model 


$\begin{aligned} \mathrm{H} 2: & \text { Portofolio yang dibentuk } \\ & \text { menggunakan stochastic } \\ & \text { dominance lebih optimal dari } \\ & \text { pada portofolio yang dibentuk } \\ & \text { menggunakan single index } \\ & \text { model } \\ \mathrm{H} 3: & \text { portofolio yang dibentuk } \\ & \text { menggunakan single index } \\ & \text { model lebih optimal dari pada } \\ & \text { portofolio yang dibentuk } \\ & \text { menggunakan stocahastic } \\ & \text { dominance. }\end{aligned}$

\section{KAJIAN PUSTAKA}

Investasi

Investasi adalah komitmen atas sejumlah dana atau sumber daya lainnya yang dilakukan pada saat ini, dengan tujuan memperoleh sejumlah keuntungan dimasa yang akan datang. (Tandelilin, 2010:2).Investasi dapat didefinisikan sebagai penundaan konsumsi sekarang untuk dimasukkan ke aktiva produktif selama periode waktu yang tertentu. Dengan adanya aktiva yang produktif, penundaan konsumsi sekarang untuk diinvestasikan ke aktiva yang produktif tersebut akan meningkatkan utiliti total. (Hartono, 2016:5)

Return dan Risiko Investasi

Menurut Fahmi (2015:166) return adalah keuntungan yang diperoleh oleh perusahaan, individu dan institusi dari hasil kebijakan investasi yang dilakukannya.Return atau hasil investasi adalah penghasilan (gain) atau kerugian (loss) karena turunnya nilai investasi pada suatu periode tertentu. Return merupakan hasil yang diperoleh dari investasi. Return dapat dibedakan menjadi 2 yaitu :

Return realisasi (realized return) merupakan return yang telah terjadi. Return realisasi dihitung menggunakan data historis. Return realisasi penting \karena digunakan sebagai salah satu pengukuran kinerja dari perusahaan. Return realisasi berguna sebagai dasar penentuan return ekspektasian (expected return) dan risiko dimasa datang.

Return ekspetasi (expected return) adalah return yang diharapkan akan diperoleh oleh investor dimasa mendatang. return ekspektasian sifatnya belum terjadi. (Hartono, 2016:283) Pengukuran return yang digunakan adalah return total (total return), relatif return (return relative), kumulatif return (return cumulative) dan return disesuaikan (adjusted return). Return totalmerupakan return keseluruhan dari suatu investasi dalam suatu periode yang tertentu yaitu: Return = capital gain (loss) ditambah dengan yield, sedangkan capital gain (loss) merupakan selisih dari harga investasi sekarang relatif dengan harga periode yang lalu atau $\left(\mathbf{P}_{\mathbf{t}}-\right.$ Pt-1)/ Pt-1.Yield merupakan persentase penerimaan kas periodik terhadap harga investasi periode tertentu dari suatu investasi. Untuk saham, yield adalah persentase dividen terhadap harga saham periode sebelumnya..Untuk saham biasa yang membayar dividen secara periodik sebesar Dt rupiah perlembarnya, maka yield adalah sebesar Dt/ Pt-1 dan return total sebagai berikut :(Pt - Pt-1)/ Pt- 1ditambah Dt/ Pt- 1 Selain return investasi erat kaitannya dengan risiko. Dimana 
risiko menurut Fahmi (2015: 165) risiko dapat ditafsirkan sebagai bentuk keadaan ketidakpastian tentang suatu keadaan yang akanterjadi nantinya (future) dengan keputusan yang diambil berdasarkan berbagai pertimbangan pada saat ini, risiko merupakan besarnya penyimpangan antara pengambilan yang diharapkan (expected return) dengan tingkat pengembalian yang dicapai secara nyata (actual return). Semakin besar terjadinya penyimpangan dapat diartikan semakin besar pula tingkat risikonya.

\section{Teori Portofolio}

Portofolio merupakan bidang ilmu mengkaji tentang bagaimana cara yang dilakukan oleh seorang investor untuk menurunkan risiko dalam berinvestasi secara seminimal mungkin termasuk salah satunya dengan penganekaragaman risiko tersebut (Fahmi, 2015:2). Portofolio berarti sekumpulan investasi. Tahap ini menyangkut identifikasi sekuritas - sekuritas mana yang akan dipilih daan berapa proporsi dana yang akan ditanamkan pada masing - masing sekuritas tersebut. Pemilihan banyak sekuritas dimaksudkan untuk mengurangi risiko yang ditanggung. Sebagaimana telah disebutkan pemilihan sekuritas ini dipengaruhi oleh prefensi risiko, pola kebutuhan kas, status pajak dan sebagainya. (Husnan, 1998:49)

Portofolio efisien dan Portofolio Optimal

Portofolio efisien (efficient portfolio) adalah portofolio yang berada dalam kelompok (set) yang layak menawarkan ke para investor ekspektasi return maksimum atas berbagai level risiko dan juga risiko minimum untuk berbagai level ekspetasi return (Fahmi,2015:3)

Portofolio efisien adalah portofolio dengan return tinggi pada risiko tertentu atau portofolio dengan risiko terendah pada return tertentu (Tandelilin, 2010:157). Portofolio optimal adalah portofolio yang dipilih seorang investor dari sekian banyak pilihan yang ada pada kumpulan portofolio efisien. Portofolio yang dipilih investor merupakan portofolio yang sesuai dengan preferensi investor bersangkutan terhadap return dan terhadap risiko yang bersedia ditanggung oleh investor (Tandelilin, 2010:157).

Single index model (indeks tunggal)

Model indeks tunggal didasarkan pada pengamatan bahwa harga dari suatu sekuritas berfluktuasi searah dengan indeks harga pasar (Hartono 2016: 427).Kebanyakan saham cenderung mengalami kenaikan harga jika indeks harga saham naik dan jika indeks harga turun, kebanyakan saham mengalami penurunan harga.Dengan demikian return dari sekuritas mungkin berkorelasi karena adanya reaksi umum terhadap perubahan perubahan nilai pasar. Tingkat keuntungan masing - masing saham dapat dihitung sebagai berikut: Return $=\mathrm{Pt}_{\mathrm{t}}-\mathrm{Pt}-1 / \mathrm{Pt}-1$ Model index tunggal mendasarkan pemikiran bahwa tingkat keuntungan pasar berkorelasi dengan perubahan pasar (Husnan, 1998:103). Model ini banyak digunakan sebagai alat analisis untuk mendapatkan portofolio yang efisien, karena bisa memberikan return yang optimal. 


\section{Stochastic dominance}

Stochastic dominance merupakan teknik yang tidak memeperhatikan bagaimana distribusi tingkat keuntungan investasi - investasi yang sedang dipertimbangan.Dengan kata lainstochactic dominance tidak menyaratkan distribusi tingkat keuntungan harus bersifat normal.Stochastic dominance menggunakan tiga asumsi yaitu first order, second order dan third order.First order stochastic dominance menyatakan bahwa pemodal lebih menyukai yang banyak dari pada sedikit.Second order stochastic dominance menyatakan bahwa pemodal bersikap tidak menyukai risiko. Sedangkan third order stochastic dominance menyatakan bahwa pemodal mempunyai decreasing absolute risk aversion( Husnan, 1998:146). Stochastic dominance adalah penerapan prinsip dominance untuk distribusi yang tidak pasti.Stochastic dominance sebagai sebuah keputusan aturan bertujuan untuk mengklarifikasikan keputusan kedalam seperangkat yang efisien menggunakan fakta bahwa utilitas fungsi memuaskan satu atau kedua karakteristik tanpa mengasumsikan yang lain kelas fungsional atau bentuk fungsi utilitas. (Adeyemo, 2013 : 79).

\section{METODE PENELITIAN}

Penelitian menggunakan metode kuantitatif dengan pendekatan deskriptif dengan menganalisis dan menggambarkan pembentukan portofolio optimal dengan stochastic dominanace model dan single index model berdasarkan fakta - fakta yang dapat dilihat dan diamati. Penelitian dilakukan di Bursa Efek
Indonesia yang di akses dengan website resmi www.idx.co.id untuk saham saham yang masuk dalam sektor real estate and property selama 5 tahun yaitu pada tahun $(2013$ - 2017).

\section{Teknik Pengambilan Sampel Populasi dan sampel}

Populasi dalam penelitian ini adalah perusahaan real estate and property yang terdaftar di Bursa Efek Indonesia selama lima tahun yaiutu dari tahun 2013 - 2017. Adasebanyak 49 perusahaan yang masuk dalam sektor real estate and property yang tercatat dengan teknik kriteria pengambilan sampel purposive sampling ada 19 perusahaan yang terpilih. Pengambilan sampel dilakukansecara purposive sampling dimana sampel diambil berdasarkan kriteria yang telah ditetapkan oleh peneliti, yaitu :

perusahaan real estate and property yang selalu mengeluarkan laporan keuangannya selama periode penelitian

perusahaan real estate and property yamg tercatat mempunyai kinerja positif selama periode penelitian.

\section{Definisi Operasional Variabel}

Variabel pada penelitian ini adalah:

Return

Return sendiri adalah keuntungan yang diperoleh perusahaan, individu ataupun institusi dari hasil investasi. Secara umum rumus yang digunakan untuk menghitung return adalah : Ri $=\mathrm{Pt}-\mathrm{Pt}-1 / \mathrm{Pt}-1$

Expected return saham

Merupakan tingkat return atau pengembalian yang diharapkan oleh investor. Dirumuskan sebagai berikut 


$$
E\left(R_{t}\right) \frac{{ }^{n}{ }^{i j}{ }}{n}
$$

Risiko pasar adalah kerugian yang mungkin akan dialami oleh para investor dapat dihitung dengan

$$
{ }_{M}^{2} \underline{R}_{i j}^{{ }^{n} E R} n^{M^{2}}
$$

Menghitung probabilitas merupakan peluang atau kemungkinan terjadinya kejadian dalam suatu peristiwa dapat dicari dengan

$$
\text { Prob }=\mathbf{X} / \sum \mathbf{X}
$$

\section{Stochastic Dominance}

Stochastic dominance merupakan teknik yang tidak memeperhatikan bagaimana distribusi tingkat keuntungan investasi - investasi yang sedang dipertimbangan. Stochastic dominance tiga asumsi yaitu :

First order yaitu menyatakan bahwa pemodal lebih menyukai yang banyak dari pada sedikit, dalam artian pemodal lebih menyukai yang banyak risikonya (risk taker) dari pada yang risikonya sedikit.F $(X) \leq G$ (X) dan $\mathrm{F}(\mathrm{X})<\mathrm{G}(\mathrm{X}) \ldots .$. rumus dari (Adeyemo, Adekunle M, 2013 : 82)

Second orderadalah menyatakan bahwa pemodal bersikap tidak menyukai risiko. Sumber : (Adeyemo,Adekuntle M, 2013:83).

\section{Third order}

Third order menyatakan bahwa pemodal mempunyai decreasing absolute risk aversion atau tidak percaya akan risiko. Sumber : (Adeyemo,Adekuntle M, 2013:83)
Single Index Model

Menurut Hartono (2016:427) model indeks tunggal didasarkan pada pengamatan bahwa harga dari suatu sekuritas berfluktuasi searah dengan indeks harga pasar.Secara khusus dapat diamati bahwa kebanyakan saham cenderung mengalami kenaikan harga jika indeks harga saham naik dan jika indeks harga turun, kebanyakan saham mengalami penurunan harga. $\mathrm{ERB}_{\mathrm{i}}=\mathrm{E}\left(\mathrm{R}_{\mathrm{i}}\right) \quad-$ $\mathrm{RBR} / \beta \mathrm{idimana} \mathrm{ERB}_{\mathrm{i}}=$ excess return to beta sekuritas ke - I; $\mathrm{E}\left(\mathrm{R}_{\mathbf{i}}\right)$ $=$ return ekspetasian berdasarkan model indekstunggal untuk sekuritas ke $-\mathrm{I} ; \mathrm{RBR}=$ return aktiva bebas risiko dan $\beta \mathrm{i}=$ Beta sekuritas $\mathrm{ke}-\mathrm{i}$.

\section{Teknik Pengolahan Data}

Teknik pengolahan data dalam penelitian ini dengan menghitung model stochastic dominance dan single index model, serta menggunakan SPSS dengan uji Beda rata - rata. Dengan langkah sebagai berikut:

\section{Analisis Data dan Uji Hipotesis}

Analisis Data

Teknik analisis data yang digunakan pada penelitian ini adalah analisis stochastic dominance dan single index model. Degan mencari Stochastic dominance dan single indeks.dengan tahapan sebagai berikut :

\section{Stochastic dominanace} Menghitung return realisasi

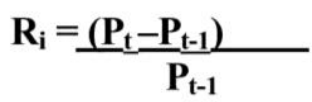

Mengurutkan saham secara sort ascending

Menentukan semua pasangan saham yang muungkin terjadi pada saham 
Menentukan probabilitas setiap saham

Menghitung first order $\mathbf{F}(\mathbf{X}) \leq \mathbf{G}(\mathbf{X})$ dan $\mathbf{F}(\mathrm{X})<\mathbf{G}(\mathrm{X})$

Menghitung second order

Menghitung third order

\section{Single index model}

Menghitung return realisasi

$$
\mathbf{R}_{\mathrm{i}}=\frac{\left(\mathbf{P}_{\mathrm{t}}-\mathbf{P}_{\mathrm{t}-1}\right)}{\mathbf{P}_{\mathrm{t}-1}}
$$

Keterangan :

$\mathrm{R}_{\mathrm{i}}=$ tingkat keuntungan saham

$\mathrm{Pt}_{\mathrm{t}}=$ harga saham individu akhir periode

$\mathrm{P}_{\mathrm{t}-1}=$ harga saham individu awal periode

$\mathrm{D}_{\mathrm{t}}=$ deviden saham yang diterima pada saham $\mathrm{i}$

Menghitung $\alpha$ dan $\beta$

$$
\begin{aligned}
& \quad \underline{n}\left(\underline{R}_{\underline{M}}\right) \underline{R}_{i} \underline{R}_{\underline{M}} \underline{R}_{i} \\
& n\left(R_{M} \quad\right)^{2} R^{{ }_{M}} \\
& { }_{i} E R_{t}{ }_{i} E R_{M}
\end{aligned}
$$

Menghitung return ekspetasi $\left(E\left(R_{i}\right)\right)$

$$
E\left(R_{t}\right) \frac{{ }^{n} R_{i j}}{n}
$$

Menghitung return ekspetasi $\operatorname{pasar}\left(\mathbf{E}\left(\mathbf{R}_{\mathbf{m}}\right)\right)$

$$
E\left(R_{M}\right)^{R_{\underline{M}}}
$$

\section{Menghitung tingkat Risiko} pasar

$$
{ }_{M}^{2} \frac{R^{n} E R}{{ }_{i j}} n^{M^{2}}
$$

\section{Menentukan varian dari kesalahan risidu \\ $e_{i} \quad=R_{i}-\alpha_{i}-\left(\beta_{i} \cdot R_{m}\right)$}

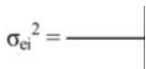

Maka total risiko adalah : $\sigma_{\mathrm{i}}^{2} \quad=\beta_{\mathrm{i}}{ }^{2} \cdot \sigma_{\mathrm{m}}{ }^{2}+\sigma_{\mathrm{ei}^{2}}$

Keterangan :

$\sigma_{\mathrm{ei}}{ }^{2}=$ varian ei atau risiko unik

$\beta_{\mathrm{i}}{ }^{2} \quad=$ beta saham

$\sigma_{\mathrm{m}}{ }^{2}=$ varian dari keuntungan pasar

$\sigma_{i}^{2} \quad=$ varian dari keuntungan saham

\section{Timgkat keuntungan bebas} risiko

tingkat keuntungan bebas risiko yang digunakan adalah tingkat suku bunga Sertifikat Bank Indonesia (SBI) selama periode penelitian.

\section{Menghitung Excess return to} beta (ERB)

$$
\mathbf{E R B}=\frac{\mathbf{E}\left(\mathbf{R}_{\mathbf{i}}\right)-\mathbf{R}_{\mathbf{B R}}}{\boldsymbol{\beta}_{\mathbf{i}}}
$$

Keterangan :

$$
\begin{aligned}
\mathrm{Bi}_{\mathrm{i}}= & \text { Beta saham } \mathrm{i} \\
\mathrm{E}\left(\mathrm{R}_{\mathrm{i}}\right)= & \text { tingkat keuntungan } \\
& \text { yang di harapkan } \\
& \text { dari saham } \mathrm{i} \\
\mathrm{RBR}= & \text { return aktiva bebas } \\
& \text { risiko }
\end{aligned}
$$

Sumber : (Jogiyanto, 2016:362)

\section{Menghitung $\mathrm{Ai}$ dan $\mathrm{Bi}$}

$A_{i}=\frac{\left[\mathbf{E}\left(\mathbf{R}_{\mathrm{i}}\right)-\mathbf{R}_{\mathrm{BR}}\right.}{\sigma_{\mathrm{ei}}{ }^{2}} \underline{\boldsymbol{\beta}_{\mathrm{i}}}$

$\mathbf{B}_{\mathrm{i}}=\frac{\boldsymbol{\beta}_{\mathrm{i}}{ }^{2}}{\boldsymbol{\sigma}_{\mathrm{ei}}{ }^{2}}$

Keterangan :

$\mathrm{A}_{\mathrm{i}}=$ penentuan nilai cutoff point rate saham

$\mathrm{AB}_{\mathrm{i}} \quad=$ penentuan nilai $c u t-$ off point rate saham

$\mathrm{BRBR}=$ keuntungan aktiva bebas risiko

$\mathrm{E}\left(\mathrm{R}_{\mathbf{i}}\right)$ = tingkat keuntungan yang diharapkan dari saham i

$\mathrm{B}_{\mathrm{i}}=$ Beta saham $\mathrm{i}$

$\sigma e i^{2}=$ varian ei atau risiko unik 
Menghitung cut of rate (Ci)

$$
\mathbf{C i}=\underline{\sigma} \underset{\mathrm{m}}{\underline{2}}
$$

\section{MenghitungWi dan $\mathrm{Z}$}

$$
\mathbf{W}_{\mathbf{i}}=\underline{\mathbf{Z}_{\mathbf{i}}}
$$

Sumber: (Jogiyanto, 2016:366)

\section{Menghitung return portofolio yang terbentuk \\ $\mathrm{Rp}=$}

$$
\begin{aligned}
& Z_{i}=B_{i}^{2} \\
& \sigma_{e i}{ }^{2} \\
& \left(E R B i-C^{*}\right)
\end{aligned}
$$

Sumber: (Jogiyanto, 2016:367)

Portofolio dikatakan optimal apabila:

Mampu memberikan expected return terbesar dengan risiko minimum.

Mampu memberikan risiko terkecil dengan expected return yang terbaik.

\section{Uji Hipotesis}

Uji t

Untuk menguji hipotesis pada penelitian ini peneliti menggunakan uji parsial (uji statistic t). Uji statistic $\mathrm{t}$ pada dasarnya menunjukkan seberapa jauh pengaruh suatu variabel penjelas/independen secara individual dalam menerangkan variasi variabel dependen. (Ghozali, 2016). Pengujian hipotesis secara parsial bertujuan untuk mengetahui pengaruh dan signifikansi dari masing - masing variabel independen terhadap variabel dependen. Hipotesis diterima jika output yang dihasilkan SPSS berada pada level of significance kurang dari $5 \%(<0,05)$, sebaliknya jika nilai signifikansi yang dihasilkan lebih besar dari $5 \%(>0,05)$ maka hipotesis yang diajukan tidak dapat diterima.

\section{Uji beda (independent sample $t$ test)}

Independent sample t test digunakan untuk menentukan apakah dua sampel yang tidak berhubungan memiliki nilai rata - rata yang berbeda (Ghozali, 2016). Uji beda ttest dilakukan dengan cara membandingkan perbedaan rata rata dengan standart error dari perbedaan rata - rata dua sample atau secara rumus dapat ditulis sebagi berikut: Rata-rata sampel pertama rata-rata sampel kedua Dibagi dengan standart error perbedaan ratarata kedua sampel. Terdapat dua uji beda t-test yaitu two tailed (jika hubungan kedua variabel belum diketahui) dan one tailed (jika hubungan kedua variabel sudah diketahui kecenderungannya berhubungan positif atau negative). $(=0,05) \quad \alpha$ yang digunakan dalam penelitian ini Ho diterima jika probabilitas ( $\mathrm{p}$ value) $\geq 0,05$. Pengambilan keputusannya didasarkan pada perbandingan probabilitas yang dihasilkan uji dengan nilai tingkat kepercayaan Ho ditolak jika probabilitas $(\mathrm{p}$ value $) \leq 0,05$.

\section{HASIL DAN PEMBAHASAN}

\section{Hasil Pengujian Hipotesis Stochastic dominance}

Stochastic dominance merupakan teknik pembentukan portofolio tanpa memeperhatikan tingkat distribusi normal. Dengan menghitung return masing - masing saham secara individual dengan mencatat return masing - masing saham dari yang terkecil sampe yang terbesar (sort ascending) dan menentukan probabilitas untuk setiap saham. Dengan menggunakan periode pengamatan pada penelitian selama 60 bulan, maka probabilitas untuk 
setiap emiten sebesar 1/60 atau 0,016. Seluruh return dan probabilitas untuk setiap saham emiten dalam 60 bulan dikumpulkan dan diperingkat dari yang minimal sampai maksimal. Apabila return saham ada yang probabilitasnya sama maka dikumpulkan. Kemudian menghitung first orderdan second order menghitung third order stochastic dominance. Menghitung third order stochastic dominance dilakukan apabila tidak diidentifikasi saham dominan pada second order. Apabila saham sudah teridentifikasi pada second order maka tidak perlu mengidentifikasi menggunakan third order. Dibawah ini adalah hasil secara keseluruhan mengenai dominan secara stochastic dan tidak dominan secara stochastic dariseluruh sampel penelitian ini dapat di lihat dalam tabel 1 berikut ini.

\section{Tabel 1. Hasil Donimasi Antar Pasangan Saham Real Estate and Property}

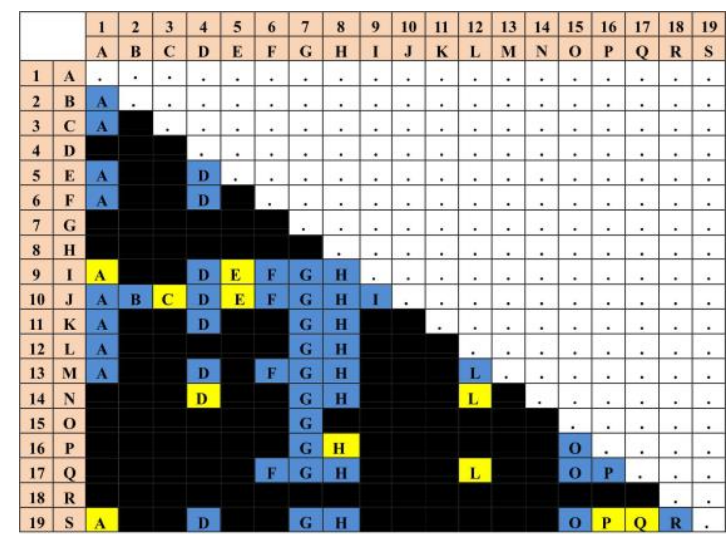

Sumber: Data sekunder yang diolah 2018

\section{Keterangan :}

$\mathbf{A}=$ Agung Podomoro Land Tbk $(\mathrm{APLN}), \mathbf{B}=$ Alam Sutera Realty Tbk (ASRI), $\mathbf{C}=$ Sentul City

Tbk (BKSL), D = Bumi Seerpong Damai Tbk (BSDE), $\mathbf{E}=$ Ciputra
Development $\operatorname{Tbk}(\mathrm{CTRA}), \mathbf{F}=$ Intiland Development Tbk(DILD), $\mathbf{G}=$ Duta Pertiwi Tbk(DUTY), H = Jaya $\quad$ Real Property Tbk(JRPT), I= Kawasan Industry Jababeka Tbk(KIJA), J= Lippo Cikarang Tbk(LPCK), K= Lippo Karawaci Tbk(LPKR), $\mathbf{L}=$ Modernland Realty Tbk(MDLN), M= Metropolitan Land Tbk(MTLA), $\quad \mathbf{N}=\quad$ Nirvana Development Tbk(NIRO), $\mathbf{O}=$ Plaza Indonesia Realty Tbk(PLIN), $\quad \mathbf{P}=$ Pakuwon Jati Tbk(PWON), Q= Pikko Land Development Tbk(RODA), $\mathbf{R}=$ Dadanayasa Artatama Tbk(SCBD), $\mathbf{S}=$ Summarecon Agung Tbk(SMRA).

$\begin{aligned} \square= & \text { second order } \\ & \text { stominance } \\ \square= & \text { third order } \quad \text { stochastic } \\ & \text { dominance } \\ = & \text { tanpa dominasi }\end{aligned}$

Berdasarkan tabel 1 dapat dijelaskan sebagai berikut: (1) Pada diagonal (misal A dan A) tidak dihitung sebagai pasangan. (2) Pasangan A dan B menunjukkan dominan pada second order ditandai dengan sel warna biru, umtuk pasangan $\mathrm{A}$ dan $\mathrm{S}$ menunjukkan dominan pada third order ditandai dengan sel warna kuning. (3) Dan sebagai contoh pasangan $\mathrm{A}$ dan $\mathrm{D}$ menunjukkan tidak ada dominasi ditandai dengan sel warna gelap. Diagram 1 menunjukan dominasi dominasi stochastic dominance.

Diagram 1. Jumlah Dominasi Stochastic Dominance:

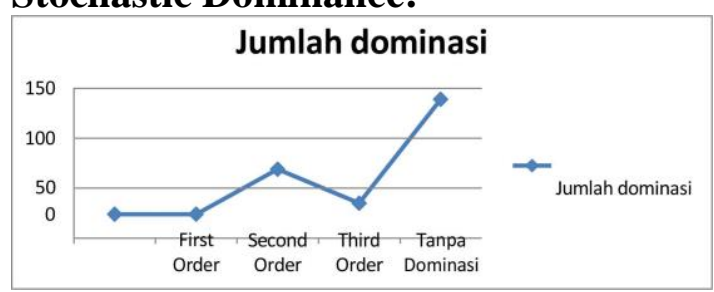


Dari tabel 1 adalah tidak terdapat first order stochastic dominance antar pasangan saham, terdapat sebanyak 45 pasangan saham second order stochastic dominance, terdapat 11 pasangan saham third order stochastic dominance dan terdapat sebanyak 115 pasangan saham diidentifikasikan tanpa dominasi secara stochastic. Temuan dalam pencatatan hasil dominasi secara stochastic pada tabel 1 dapat diketahui peringkat saham pada tabel 2 adalah sebagai berikut:

Tabel 2

\section{Peringkat Saham-Saham Real Estate} and Property DenganStochastic

Dominance

\begin{tabular}{|c|c|c|c|}
\hline $\begin{array}{c}\text { Peringkat } \\
\text { saham }\end{array}$ & Kode saham & saham & Jumlah dominasi \\
\hline 1 & A & APLN & 16 \\
\hline 2 & G & DUTI & 10 \\
\hline 3 & H & JRPT & 9 \\
\hline 4 & D & BSDE & 8 \\
\hline 5 & F & DILD & 4 \\
\hline 6 & K & LPKR & 3 \\
\hline 7 & O & PLIN & 3 \\
\hline 8 & E & CTRA & 2 \\
\hline 9 & P & PWON & 2 \\
\hline 10 & B & ASRI & 1 \\
\hline 11 & C & BKSL & 1 \\
\hline 12 & I & KIJA & 1 \\
\hline 13 & Q & RODA & 1 \\
\hline 14 & R & SCBD & 1 \\
\hline 15 & J & LPCK & - \\
\hline 16 & K & LCKR & - \\
\hline 17 & L & MDLN & - \\
\hline 18 & M & MTLA & - \\
\hline 19 & S & SMRA & - \\
\hline
\end{tabular}

Sumber: data sekunder yang diolah 2018

Setelah mengetahui dominasi saham yang masuk dalam stochastic maka selanjutnya adalah:

Membentuk portofolio saham yang dominan dengan menghitung return yang diharapkan dari portofolio tersebut dengan rumus $\mathbf{E}(\mathbf{R p})=\mathbf{X}_{\mathbf{A}}$ $\mathbf{E}\left(\mathbf{R}_{\mathrm{A}}\right)+\mathbf{X}_{\mathbf{B}} \mathbf{E}\left(\mathbf{R B}_{\mathbf{B}}\right)$

Dari hasil perhitungan diketahui $\mathrm{E}(\mathrm{Ri})$ untuk saham dengan stochastic ditampilkan di tabel 3 dibawah ini:
Tabel 3

Perhitungan E( $\left.\mathbf{R}_{\mathbf{i}}\right)$ Saham - Saham Stochastic Dominance

\begin{tabular}{|c|c|c|}
\hline No & Nama perusahaan & E(Ri) \\
\hline 1 & APLN & $-0,00068$ \\
\hline 2 & DUTI & 0,009733 \\
\hline 3 & JRPT & 0,013300 \\
\hline 4 & BSDE & 0,008400 \\
\hline 5 & DILD & 0,009383 \\
\hline 6 & MDLN & 0,016250 \\
\hline 7 & PLIN & 0,021817 \\
\hline 8 & CTRA & 0,008150 \\
\hline 9 & PWON & 0,010977 \\
\hline 10 & ASRI & 0,004867 \\
\hline 11 & BKSL & 0,021938 \\
\hline 12 & KIJA & 0,007283 \\
\hline \hline 13 & RODA & 0,031000 \\
\hline 14 & SCBD & 0,048867 \\
\hline
\end{tabular}

Sumber: data sekunder yang diolah 2018

Setelah di peroleh $E\left(R_{i}\right)$ maka selanjutnya menghitung proporsi dana $\mathrm{Xi}$ dan $\mathrm{E}(\mathrm{Ri})$ dapat dilihat pada tabel 4 dibawah ini:

\section{Tabel 4. Proporsi $X_{i}$ dan $E\left(R_{p}\right)$ Stochastic Dominance}

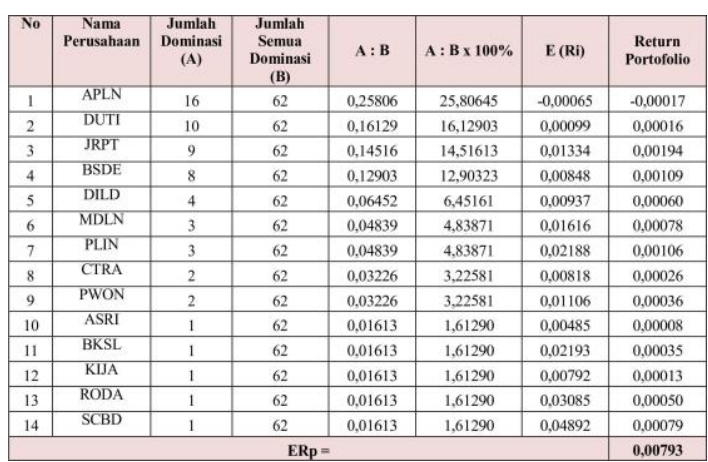

Sumber: data sekunder yang diolah 2018

\section{Single index model}

Single index model didasarkan pada pengamatan bahwa harga dari sebuah sekuritas berfluktuasi searah dengan indeks harga pasar. Berikut langkah langkah pembentukan portofolio optimal menggunakan metode single index model:

Mengitung return dari masing masing saham individual

Menghitung $\alpha$ dan $\beta$ 
Tabel 5 dibawah ini adalah perhitungan Alfa dan beta perusahaan Real Estate and Properti

Perhitungan Alfa dan Beta Saham Saham Real Estate and Property

\begin{tabular}{|c|c|c|c|}
\hline No & $\begin{array}{c}\text { Kode } \\
\text { Perusahaan }\end{array}$ & Beta & Alfa \\
\hline 1 & APLN & 0,145567 & $-0,00222$ \\
\hline 2 & ASRI & 0,107239 & 0,003733 \\
\hline 3 & BKSL & 1,369706 & 0,00746 \\
\hline 4 & BSDE & $-0,01871$ & 0,008598 \\
\hline 5 & CTRA & $-0,04495$ & 0,008625 \\
\hline 6 & DILD & 0,294907 & 0,006266 \\
\hline 7 & DUTI & $-0,01418$ & 0,009883 \\
\hline 8 & JRPT & 0,389187 & 0,009186 \\
\hline 9 & KIJA & 0,185861 & 0,005319 \\
\hline 10 & LPCK & 0,243359 & 0,018978 \\
\hline 11 & LPKR & 0,050585 & 0,006732 \\
\hline 12 & MDLN & 0,059465 & 0,015621 \\
\hline 13 & MTLA & 0,706707 & 0,01278 \\
\hline 14 & NIRO & 1,777661 & $-0,00021$ \\
\hline 15 & PLIN & 0,261202 & 0,019056 \\
\hline 16 & PWON & $-0,11151$ & 0,012155 \\
\hline 17 & RODA & 0,783309 & 0,02272 \\
\hline 18 & SCBD & 2,680051 & 0,020538 \\
\hline 19 & SMRA & $-0,09389$ & 0,014942 \\
\hline & & & \\
\hline
\end{tabular}

Sumber: data sekunder yang diolah 2018

Setelah tingkat alfa dan beta diketahui maka akan dilakuan perhitungan menghitung expected return, tingkat return pasar, return ekspektasi pasar, tingkat risiko pasar, tingkat keuntungan bebas risiko dengan tingkat keuntungan bebas risiko yang digunakan adalah tingkat suku bunga Sertifikat Bank Indonesia (SBI) selama periode penelitian, excess return to beta, Ai dan $\mathrm{Bi}$ saham, cut of rate $(\mathrm{Ci})$, Menghitung $\mathrm{Wi}$ dan $\mathrm{Zi}$, dan menghitung return portofolio yang terbentuk. Tabel 6 dibawah adalah tabel untuk mencari kandidat portofolio optimal dengan single index.
Tabel 6. ERbi dan Ci dengan Single Index Model

\begin{tabular}{|c|c|c|c|c|}
\hline No & $\begin{array}{c}\text { Nama } \\
\text { Perusahaan }\end{array}$ & ERbi & Ci & Keterangan \\
\hline 1 & APLN & $-0,06477$ & 0,00727 & $\mathrm{~T}$ \\
\hline 2 & ASRI & $-0,03667$ & $-0,0012$ & $\mathrm{~T}$ \\
\hline 3 & BKSL & 0,0096 & 0,00698 & $\mathrm{M}$ \\
\hline 4 & BSDE & 0,01625 & 0,00001 & $\mathrm{~T}$ \\
\hline 5 & CTRA & 0,01328 & 0,00003 & $\mathrm{~T}$ \\
\hline 6 & DILD & 0,00199 & 0,00025 & $\mathrm{M}$ \\
\hline 7 & DUTI & $-0,07087$ & $-0,00002$ & $\mathrm{~T}$ \\
\hline 8 & JRPT & 0,01171 & 0,00174 & $\mathrm{M}$ \\
\hline 9 & KIJA & $-0,00462$ & $-0,0003$ & $\mathrm{~T}$ \\
\hline 10 & LPCK & 0,05275 & 0,00168 & $\mathrm{M}$ \\
\hline 11 & LPKR & $-0,02857$ & $-0,0001$ & $\mathrm{~T}$ \\
\hline 12 & MDLN & 0,1242 & 0,0003 & $\mathrm{M}$ \\
\hline 13 & MTLA & 0,01616 & 0,00472 & $\mathrm{M}$ \\
\hline 14 & NIRO & 0,00542 & 0,00545 & $\mathrm{M}$ \\
\hline 15 & PLIN & 0,05016 & 0,00183 & $\mathrm{M}$ \\
\hline 16 & PWON & $-0,02043$ & $-0,0002$ & $\mathrm{~T}$ \\
\hline 17 & RODA & 0,02818 & 0,00626 & $\mathrm{M}$ \\
\hline 18 & SCBD & 0,01498 & 0,01179 & $\mathrm{M}$ \\
\hline 19 & SMRA & $-0,05661$ & $-0,0004$ & $\mathrm{~T}$ \\
\hline
\end{tabular}

Sumber: data sekunder yang diolah 2018

Keterangan:

M = Masuk kandidat portofolio $\mathbf{T}=$ Tidak masuk kandidat portofolio

Setelah diperoleh kandidat portofolio maka dapat dihitung $\mathrm{Zi}$ dan Wi dari 10 saham yang masuk dalam kandidat portofolio. Dapat dijelaskan dari tabel 7

Tabel 7

Perhitungan cut of rate $(\mathrm{Ci})$, Menghitung Wi dan $\mathrm{Zi}$

\begin{tabular}{|r|c|c|c|c|}
\hline \multicolumn{1}{|c|}{ No } & $\begin{array}{c}\text { Nama } \\
\text { Perusahaan }\end{array}$ & $\mathbf{C i}$ & $\mathbf{Z i}$ & $\mathbf{W i}$ \\
\hline 1 & BKSL & 0,00698 & 0,66041 & $-0,01344$ \\
\hline 2 & DILD & 0,00025 & 0,02479 & 0,00252 \\
\hline 3 & JRPT & 0,00174 & 0,16312 & 0,00167 \\
\hline 4 & LPCK & 0,00168 & 0,15854 & 0,00189 \\
\hline 5 & MDLN & 0,00030 & 0,02837 & 0,00034 \\
\hline 6 & MTLA & 0,00472 & 0,44891 & 0,00322 \\
\hline 7 & NIRO & 0,00545 & 0,52649 & 1,02883 \\
\hline 8 & PLIN & 0,00183 & 0,17219 & 0,00204 \\
\hline 9 & RODA & 0,00626 & 0,59597 & 0,00519 \\
\hline 10 & SCBD & 0,01179 & 1,11384 & $-0,03692$ \\
\hline
\end{tabular}

Dari hasil tabel 7 diatas maka dapat di peroleh tingkat Expected Return dan dijelaskan pada tabel 8 dibawah ini. 
Tabel 8

Expected Return Portofolio

Menggunakan Single Index Model

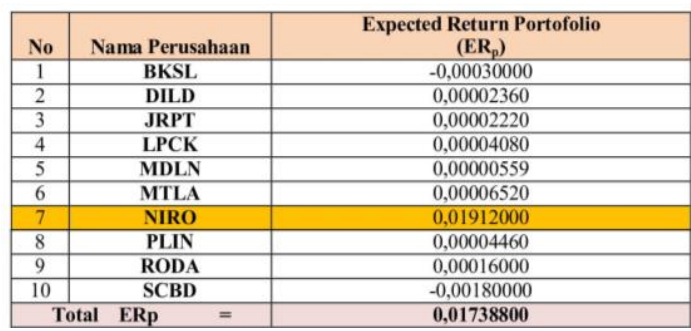

Sumber: data sekunder diolah tahun 2018

Berikut adalah diagram expected return portofolio yang dibentuk menggunakan single index model:

\section{Diagram 2 Expected Return portofolio dengan metode single index model}

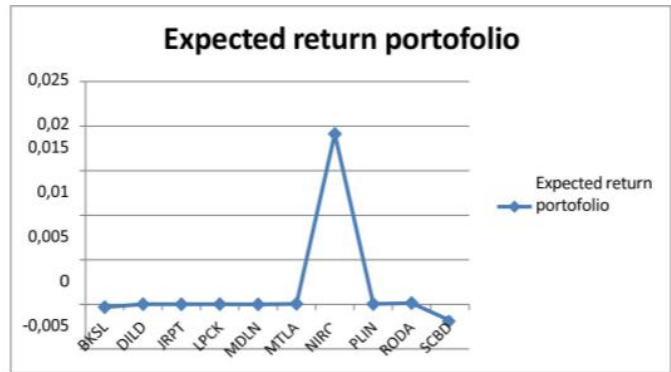

Dari diagram 2 diatas dapat dijelaskan bahwa expected return portofolio menggunakan metode single index modeluntuk saham DILD, JRPT, LPCK,MDLN,MTLA,PLIN,RODA

cenderung sama. Hanya saham NIRO yang memiliki expected return tertinggi 0,01912 serta saham BKSL dan SCBD yang memiliki expected return negatif yaitu $-0,00030$ dan $-0,00180$.

\section{Uji hipotesis}

Hasil dari uji hipotesis ditunjukan pada tabel 9

\section{Tabel 9. Hasil dari Pengujian Hipotesis}

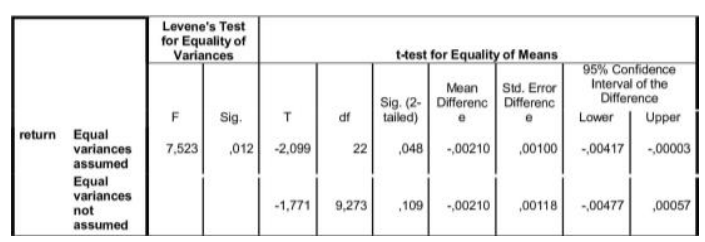

Dari hasil uji hipotesis diatas terlihat bahwa ada perbedaan antara return yang dihasilkan portofolio menggunakan stochastic dominance dengan portofolio yang dibentuk menggunakan single index model. Hal tersebut dapat dilihat dari hasil sig. (2-tailed) yang menunjukkan nilai dimana nilai tersebut lebih kecil yaitu 0,048 dari tingkat signifikan yang telah ditentukan yaitu 0,05. Hal ini dikarenakan pada penelitian ini peneliti menggunakan equal variances assumed sebagai acuan dalam menetapkan uji hipotesis.

\section{Pembahasan}

\section{Terdapat perbedaan return antara portofolio yang dibentuk menggunakan stochastic dominance dengan portofolio yang dibentuk menggunakan single index model}

Hasil penelitian membuktikan bahwa terdapat perbedaan return antara portofolio yang dibentuk menggunakan stochastic dominance dangan portofolio yang dibentuk menggunakan single index model. Hal ini dibuktikan dengan hasil analisis data penelitian yang menujukkan bahwa signifikan 2 tailed lebih kecil $(0,048)$ dari pada angka signifikan yang telah ditentukan oleh peneliti $(0,05)$.

$\mathrm{H}_{1}=$ menyatakan bahwa ada perbedaan antara portofolio yang dibentuk menggunakan single index model dengan portofolio yang dibentuk menggunakan stochastic dominance .sehingga hipotesis $\mathrm{H}_{1}$ diterima. 
Hasil penelitian ini sama dengan penelitian yang telah dilakukan oleh Abdul Khotim dkk (2014), yang menyatakan juga terdapat perbedaan return antara portofolio yang dibentuk mengguakan single index model dengan portofolio yang dibentuk menggunakan stochastic dominance.

\section{Portofolio yang dibentuk meng- gunakan stochastic dominance kurang optimal dibandingkan dengan portofolio yang dibentuk menggunakan single index model}

Hal ini ditunjukkan dengan return yang diperoleh dari portofolio yang dibentuk menggunakan stochastic dominance lebih kecil $(0,79 \%)$ dibandingkan dengan portofolio yang dibentuk menggunakan single index model $(1,73 \%)$.

Oleh karena itu dapat disimpulkan bahwa $\mathrm{H}_{2}$ = portofolio yang dibentuk menggunakan stochastic dominance lebih optimal dibandingkan portofolio yang dibentuk menggunakan single index model ditolak dan $\mathrm{H}_{0}$ diterima. Hal ini sesuai dengan penelitian yang dilakukan oleh Abdul Khotim, dkk (2014). Karena pada penelitian tersebut expected return portofolio yang dibentuk menggunakan index tunggal lebih optimal dibandingkan portofolio yang dibentuk menggunakan stochastic dominance.

\section{Portofolio yang dibentuk meng- gunakan single index model lebih optimal dibandingkan portofolio yang dibentuk menggunakan stochastic dominance}

Hal ini ditunjukkan dengan return yang diperoleh dari portofolio yang dibentuk menggunakan single index model yang lebih besar $(1,73 \%)$ dibandingkan portofolio optimal yang dibentuk menggunakan stochastic dominance adalah $(0,79 \%)$.

Oleh karena itu dapat disimpulkan bahwa $\mathrm{H}_{3}=$ portofolio yang dibentuk menggunakan menggunakan single index model lebih optimal dibandingkan dengan portofolio yang dibentuk menggunakan stochastic dominance diterima dan $\mathrm{H} 0$ ditolak. Hal ini sama dengan penelitian yang dilakukan Abdul Khotim, dkk (2014). Yang menyatakan bahwa portofolio yang dibentuk menggunakan index tunggal menghasilkan expected return yang lebih besar dibandingkan portofolio yang dibentuk menggunakan stochastic dominance.

\section{KESIMPULAN DAN SARAN}

\section{Kesimpulan}

Dari penelitian ini dapat diambil kesimpulan bahwa portofolio optimal yang terbentuk dengan menggunakan stochastic dominance dan single index model mempunyai perbedaan return. Portofolio yang dibentuk menggunakan single index model lebih optimal dalam menghasilkan return dibandingkan portofolio optimal yang dibentuk dengan menggunakan stochastic dominance model. Hal ini dapat diketahui dari hasil expected return portofolio yang dihasilkan portofolio yang dibentuk menggunakan single index model lebih besar dari pada portofolio yang dibentuk mneggunakan stochastic dominance. Sehingga pembentukkan portofolio optimal menggunakan single index model juga lebih dianjurkan untuk digunakan oleh para investor dibandingkan dengan pembentukkan menggunakan stochastic dominance.

\section{Saran}

Bagi investor dalam berinvestasi saham di pasar modal perlu mempertimbangkan banyak hal termasuk alat analisis yang digunakan untuk menentukan saham 
mana saja yang akan dipilih. Setiap alat analisis mempunyai asumsi - asumsi yang berbeda, sehingga besar kemungkinan juga akan menghasilkan kandidat saham yang berbeda pula. Berinvestasi saham dipasar modal, investor hendaknya perlu memilih saham - saham yang tepat untuk dimasukkan ke dalam portofolio serta melakukan diversifikasi saham untuk mengurangi risiko kerugian. Dalam penelitian selanjutnya perlu menambahkan metode lainseperti Capitas Asset Pricing Model (CAPM) dan objek penelitian yang luas dari berbagai sektor industri.

\section{DAFTAR PUSTAKA}

Adeyemo,Adekunte M. 2013. Stochastic Dominance for Project Screening andSelection under Uncertainty. Amerika Serikat: Massachusetts Institut of Technology

Andriyani, Farida dan Machfiroh, Lailatul D. 2016.“Analisis KomparatifPembentukan Portofolio Optimal Menggunakan Capital Asset PricingModel (CAPM) dan StochasticDominance”.Jurnal Bisnis Dan EkonomiVol.14 No. 1. April, 2016.

Fahmi, Irham.2015. Teori Portofolio dan Analisis Investasi.Bandung :Alfabeta

Ghozali, Imam. 2016. Aplikasi Analisis Multivariate dengan Program IBMSPSS 23.Semarang : Badan Penerbit Universitas Diponegoro.

Hartono, Jogiyanto.2016.Teori Portofoliodan Analisis Investasi. Yogyakarta: BPFE Yogyakarta

Husnan, Suad. 1998. Teori Portofoliodan Analisis Sekuritas.Yogyakarta :UPP AMP YKPN

Ichsanuddin, Mohammad. 2016." Analisis Portofolio Optimal Dengan Model Indeks Tunggal Pada Perusahaan Retail diBEI'.Jurnal IlmuDan RisetManajemen Vol. 5 No. 5.Mei, 2016.

Khotim, Darminto, Topowijono.2014. Analisis Pembentukan Portofolio OptimalMenggunakan Model Indeks Tunggal Dan Stochastic DominanceDalamPengambilan Keputusan Investasi (Studi Pada Saham - Saham Indeks Sri- Kehati Yang Listing Dibursa Efek Indonesia Periode Tahun 2010 2013).Jurnal Administrasi Bisnis Vol.11 No. 1.Juni, 2014.

Olofson, Peter MichaelAnderson.2011.Probability, Statistic and Stochastic Prosecesses. Texas :Jhon Wiley and Sons.Inc

Sekaran, Uma. 2011. Metodologi penelitian untuk bisnis. Jakarta :Salemba Empat

Sugiyono. 2016. Metode Penelitian Pendidikan ( Pendekatankuantitatif,Kualitatif dan $R \& D)$.Bandung : Alfabeta 
Tandelilin, Eduardus. 2010. Portofolio dan Investasi. Yogyakarta :Kanisius

Wibowo M, Rahayu M, Maria N P. 2014. "Penerapan Model Indeks TunggalUntuk Menetapkan Komposisi Portofolio Optimal (Studi Pada Saham Saham LQ45 yang Listing diBursa EfekIndonesia (BEI) tahun 2010 2012)”.Jurnal Administrasi Bisnis Vol.9 No. 1. April, 2014.

Yuniarti, Sari. 2010. "Pembentukan Portofolio Optimal Saham - SahamPerbankkan Dengan Menggunakan Model Indeks Tunggal.JurnalKeuangan Dan Perbankkan”. Jurnal AdministrasiBisnis Vol.14, No.3.September, 2010 hal : 459 - 466

Website www.idx.co.id https://www.bi.go.id www.duniainvestasi.com www.yahoofinance.com 